\title{
Large-Scale Chromatin Structure-Function Relationships during the Cell Cycle and Development: Insights from Replication Timing
}

\author{
Vishnu Dileep, ${ }^{1}$ Juan Carlos Rivera-Mulia, ${ }^{1}$ Jiao Sima,${ }^{1}$ and David M. Gilbert ${ }^{1,2}$ \\ ${ }^{1}$ Department of Biological Science, Florida State University, Tallahassee, Florida 32306-4295 \\ ${ }^{2}$ Center for Genomics and Personalized Medicine, Florida State University, Tallahassee, \\ Florida 32306-4295
}

Correspondence: gilbert@bio.fsu.edu

\begin{abstract}
Chromosome architecture has received a lot of attention since the recent development of genome-scale methods to measure chromatin interactions (Hi-C), enabling the first sequence-based models of chromosome tertiary structure. A view has emerged of chromosomes as a string of structural units (topologically associating domains; TADs) whose boundaries persist through the cell cycle and development. TADs with similar chromatin states tend to aggregate, forming spatially segregated chromatin compartments. However, high-resolution Hi-C has revealed substructure within TADs (subTADs) that poses a challenge for models that attribute significance to structural units at any given scale. More than 20 years ago, the DNA replication field independently identified stable structural (and functional) units of chromosomes (replication foci) as well as spatially segregated chromatin compartments (early and late foci), but lacked the means to link these units to genomic map units. Genome-wide studies of replication timing (RT) have now merged these two disciplines by identifying individual units of replication regulation (replication domains; RDs) that correspond to TADs and are arranged in 3D to form spatiotemporally segregated subnuclear compartments. Furthermore, classifying RDs/TADs by their constitutive versus developmentally regulated RT has revealed distinct classes of chromatin organization, providing unexpected insight into the relationship between large-scale chromosome structure and function.
\end{abstract}

Shortly after J.H. Taylor synthesized tritiated thymidine and his pre-Messelson and Stahl demonstration of semiconservative, antiparallel DNA replication (Taylor et al. 1957; Meselson and Stahl 1958), he discovered that plant and animal chromosomes replicate segmentally in a defined temporal sequence (Taylor 1958, 1960). The segments labeled during a brief pulse were too large to be accounted for by a single replicon, rather being more consistent with the coordinated initiation of replicon clusters within each segment. Later, visualization of purified DNA fibers confirmed the synchronous firing of origin clusters (Jackson and Pombo 1998; Berezney et al. 2000). Today, it is understood that these initiation sites are stochastically selected from a large set of potential initiation sites and each chromosome uses a different cohort of sites (Lebofsky et al. 2006; Hamlin et al. 2008; Cayrou et al. 2011; Letessier et al. 2011; Besnard et al. 2012). Despite this flexibility in origin choice, a defined temporal order of replication (replication timing; RT) emerges (Bechhoefer and Rhind 2012). Indeed, it is the temporal order of replication, not the initiation sites, that is conserved among species (Aladjem et al. 2002; Farkash-Amar et al. 2008; Liachko et al. 2010; Ryba et al. 2010; Yaffe et al. 2010; Di Rienzi et al. 2012; Müller and Nieduszynski 2012; Xu et al. 2012).

Blocks of synchronously firing origins can also be visualized by genome-wide RT profiling as large synchronously replicated chromosome segments, and their boundaries can be identified by monitoring the coordi- nated switches in RT that occur across half of the genome during cell fate transitions, revealing $400-800 \mathrm{~kb}$ units of replication regulation, or "replication domains (RDs)" (Hiratani et al. 2008, 2010; Hansen et al. 2010; Ryba et al. 2010). RDs are also likely to be the equivalent of the punctate "replication foci" that are seen whenever cells are briefly labeled with detectable nucleotide analogs. These foci persist through multiple cell generations, suggesting they are stable chromosome units, and foci that replicate early or late during S phase reside in separate compartments of the nucleus and correlate with transcriptional activity within each domain (Nakamura et al. 1986; Nakayasu and Berezney 1989; O'Keefe et al. 1992; Sparvoli et al. 1994; Ferreira and Carmo-Fonseca 1997; Jackson and Pombo 1998; Ma et al. 1998; Dimitrova and Gilbert 1999; Sadoni et al. 2004). Recent findings have mapped this 3D organization onto the genome sequence, providing molecular alignment of large-scale chromatin folding with RDs and their time of firing during S phase, both enhancing our understanding of the significance and mechanism of the replication program and providing a functional proxy for the molecular maps of chromosome folding (Ryba et al. 2010; Yaffe et al. 2010; Dixon et al. 2012; Moindrot et al. 2012). These results suggest a unifying model of how structural compartmentalization of the genome in the eukaryotic nucleus can influence overall functional output. Here, we summarize the novel insights that genome-wide analyses of RT have contributed to our understanding of large-scale chromosome structure and function. 


\section{BOX 1: GLOSSARY OF TERMS}

RT: Replication timing.

RD: Replication domain. A chromosome segment $(400-800 \mathrm{~kb})$ that replicates as a unit via the coordinated firing of multiple replicons.

TDP: Timing decision point. Window of time within early $\mathrm{G}_{1}$ when the RT program is established.

CTR: Constant timing region. Chromosome segment that replicates relatively synchronously, appearing as a plateau in RT profiles. A CTR may be as small as a single RD, but often consists of multiple adjacent RDs replicating at similar times creating a multimegabase CTR.

TTR: Timing transition region. Segment of DNA between early and late CTRs where a continuous change in RT is observed.

Hi-C: Chromatin conformation capture technique for measuring genome-wide contact frequency.

TAD: Topologically associating domain identified by chromatin interaction maps.

LAD: Lamina-associated domains identified by interaction with the nuclear lamina.

RT signature: Set of genome segments whose RT distinguishes a cell type from all others identified by unsupervised clustering analysis.

RT fingerprint: Set of genomic segments whose RT best distinguishes two cell types or groups of cell types in a supervised comparison.

RT feature: Individual chromosomal segment within a signature or fingerprint.

\section{GENOME-WIDE RT PROFILING: INTERPRETATION AND MISINTERPRETATION}

\section{Measuring RT Genome-Wide}

The most robust (rapid/high-dynamic-range) method for genome-wide RT profiling is to pulse-label cells with a nucleoside analog such as 5-bromo-2-deoxyuridine (BrdU) and purify early and late S-phase fractions on the basis of DNA content by flow cytometry (Gilbert 2010). BrdU-labeled DNA from each fraction is immunoprecipitated, amplified, and sequenced or hybridized to a microarray, and a ratio of enrichment of sequences in early fraction to late fraction is generated (E/L method) (Fig. 1A; Ryba et al. 2011a; Dileep et al. 2012). For nonlive cell samples (e.g., proliferating cells that were frozen or fixed), $\mathrm{RT}$ can be inferred by measuring relative copy number variation $(\mathrm{CNV})$ between cells sorted in $\mathrm{S}$ phase versus $\mathrm{G}_{1}$ phase (Woodfine et al. 2004; Gilbert 2010). This circumvents the nucleoside analog incorporation and immunoprecipitation steps, but the maximum dynamic range of the data is decreased from 1000-fold or higher for the E/L method to twofold. It is even possible to glean RT from the slight $\mathrm{CNV}$ within a genomic sequence, providing that sufficient numbers of cells were in S phase and the sequencing is deep enough to overcome noise (Manukjan et al. 2013; Dimitriadou et al. 2014; Koren et al. 2014).

\section{Interpreting RT Profiles (CTRs and TTRs)}

RT profiles from multicellular organisms consist of broad, computationally defined constant timing regions (CTRs) of relatively synchronous initiation of replication, separated by timing transition regions (TTRs) (Fig. 1B; Farkash-Amar et al. 2008; Hiratani et al. 2008; Desprat et al. 2009; Ryba et al. 2010). CTRs usually correspond to several tandem RDs that replicate at the same time; their boundaries cannot be detected because forks emanating from each RD fuse quickly. Often however, other cell types will replicate them at sufficiently different times to create a TTR and by comparing RT profiles from many cell types, increasingly more RD boundaries can be identified (Pope et al. 2014). Hence, RDs and their boundaries are cell type-invariant, whereas CTRs reflect the developmental regulation of RT. Similarly, replication within TTRs can proceed passively through one or more RDs before fusing with a late replicon or can terminate within an RD by fusing with a fork emanating from a distal early RD. As a result, only the earliest replicating border of a TTR aligns with the boundary of an RD (Pope et al. 2014). It is still a matter of debate as to whether TTRs consist of a single unidirectional fork (Norio et al. 2005; Schultz et al. 2010) or sequential firing of origins resulting in the appearance of unidirectional replication (Guilbaud et al. 2011). However, sequences that can function as origins at their normal locations initiate poorly when inserted into a TTR (Guan et al. 2009), whereas conditions of slowed fork movement (replication stress) may activate dormant origins (Blow and Ge 2009) within the TTR to accelerate its replication. Hence, both interpretations are likely to be correct under the appropriate conditions.

\section{Common Misinterpretations}

Can $R T$ profiles identify replication origins? Closer inspection of CTRs reveals a series of "earliest replicating 
A

1) Pulse label with BrdU

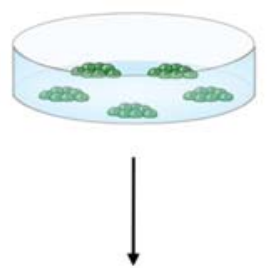

2) FACS sort

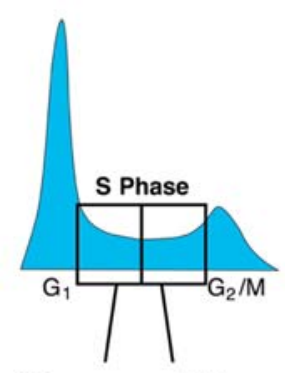

3) Immunoprecipitate nascent BrdU-DNA

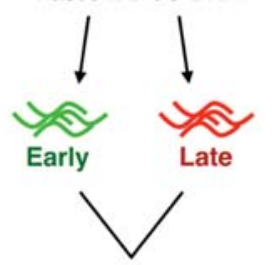

4) Sequencing
B

Chromosome 10
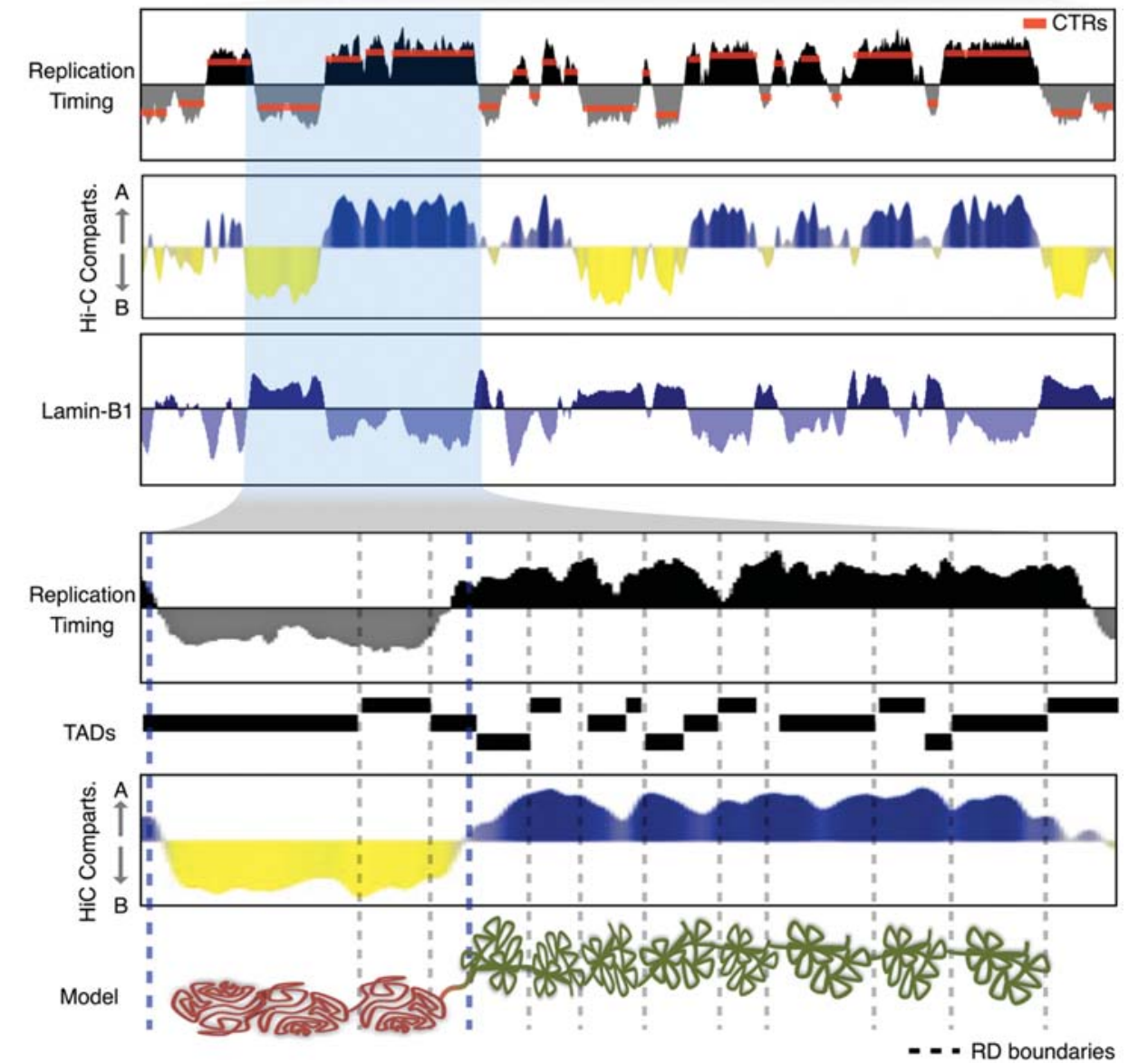

Figure 1. Measuring replication timing (RT) and its relationship to chromatin structure. $(A)$ Repli-seq method. Cells pulse labeled with BrdU are separated into early and late S-phase fractions by flow cytometry. BrdU-substituted DNA from each fraction is immunoprecipitated with an anti-BrdU antibody and subject to next-generation sequencing. ( $B$, Top) Exemplary RT profile of $50 \mathrm{Mb}$ from hChr.10 in IMR90 fibroblasts, compared with Hi-C interaction compartments (Eigenvector display) and LaminB1 contact maps (DamID). (Bottom) $10 \mathrm{Mb}$ containing large adjacent early and late synchronously replicating regions is expanded and compared with topologically associating domains (TADs) and Hi-C compartments. At the bottom is a schematic model; larger coordinately replicated regions consist of multiple tandem early (green) or late (red) replicating domains that are off or on the periphery, respectively. Blue vertical lines are replication domain (RD) boundaries identified in IMR90 and gray dotted lines are RD boundaries found in other cell types. FACS, fluorescence-activated cell sorting.

peaks," descriptively referred to as "ripples" (Mukhopadhyay et al. 2014; Bartholdy et al. 2015), that are often referred to as active replication origins (Hause and Shendure 2014; Koren et al. 2014). However, the statistical reproducibility of ripples across several biological replicates must first be rigorously determined and even then, ripples likely result from heterogeneous firing of several adjacent low-efficiency origins in the population (Rhind and Gilbert 2013). Even the sharpest and most reproducible ripples fall in the range of several tens of kilobases, sufficient to harbor multiple potential replication origins (Rhind and Gilbert 2013). Importantly, no in-depth study of these features has been performed to confirm their identity from their behavior in RT profiles. Hence, although some ripples likely represent regions of frequent initiation, it is misleading to refer to these initiation regions as "replication origins."

Resolution. Another common misinterpretation is that deeper sequencing and/or more extensive fractionation of the cell cycle will give increasingly higher resolution data. It is important to understand that the resolution of ensemble RT data is limited by the biology of DNA replication. Because replication forks move bidirectionally at nearly $2 \mathrm{~kb} / \mathrm{min}$ at an average spacing of $120 \mathrm{~kb}$ (Cayrou et al. 2011), most replicons within any 400-800-kb RD will complete synthesis in $30-40$ min $(<10 \%$ of $\mathrm{S}$ phase $)$. Perhaps more importantly, stochastic origin firing produces a different pattern of replication in each cell, so the averaging of thousands of cells further diminishes the 
signal from any given origin. Single-cell or single-molecule methods (Norio and Schildkraut 2001; Gilbert 2010; Schultz et al. 2010; Van der Aa et al. 2013) are needed to overcome these barriers.

Neither RDs nor CTRs Align with Chromomeric Banding Patterns. When labeled cells are chased into metaphase, a close correlation is consistently observed between banding patterns revealed by replication labeling and chromomeric R/G chromosome bands (Latt 1977; Holmquist et al. 1982; Craig and Bickmore 1993; Hoshi and Ushiki 2011). However, neither CTRs nor the much smaller RDs align to R/G bands (Fig. 1B). Presumably, this must reflect higher-order packaging of early and late replicating DNA into the metaphase chromosomes, an interesting phenomenon that deserves further study.

\section{RT IS A STABLE EPIGENETIC PROPERTY}

$\mathrm{RT}$ is a robust property resistant to most artificial perturbations of chromatin structure and transcriptional programs. Except a few localized changes, the RT program is virtually unaffected by knockout/knockdown or overexpression of many chromatin and transcription regulators, aging, and induced cellular senescence, and conditions of replication stress where origin choice is demonstrably altered population-wide (Hiratani et al. 2008; Yokochi et al. 2009; Pope et al. 2011; Ryba et al. 2012; Takebayashi et al. 2013; JC Rivera-Mulia, unpubl.). In fact, the only molecular perturbations that have been shown to cause widespread changes in RT were Rifl (16\% of genome affected) and Pol Theta (Cornacchia et al. 2012; Hayano et al. 2012; Fernandez-Vidal et al. 2014). Table 1 summarizes and ranks factors according to their effect on RT.

In contrast to the resilience of RT to artificial manipulations, cell fate changes reproducibly and extensively modify RT. RT profiles of different genetically polymorphic embryonic stem cell (ESC) lines were nearly identical. However, after differentiation of ESCs toward distinct lineages, a global reorganization of RT occurred that affected $\sim 50 \%$ of the genome and $20 \%$ of the genome between any given cell fate transition (Hiratani et al. 2008, 2010; Ryba et al. 2010; Rivera-Mulia et al. 2015). In addition, RT changes resulted in a significant increase in the average CTR size together with a drop in the number of domains, with small differentially replicated RDs consolidating into larger regions of tandem RDs that replicate at similar times during $\mathrm{S}$ phase (Hiratani et al. 2008; Ryba et al. 2010; Rivera-Mulia et al. 2015).

In summary, RT is mitotically stable and a cell typespecific epigenetic property. The stability of RT has enabled us to generate unique RT "signatures" and "fingerprints" that can distinguish cell types (Ryba et al. 2011b; Rivera-Mulia et al. 2015) and even distinguish subtypes of cancers (Ryba et al. 2012).

\section{RT IS REGULATED AT THE LEVEL OF DEFINED CHROMOSOMAL UNITS}

Cytogenetic studies have long shown that DNA synthesis can be visualized as discrete foci that complete
Table 1. List of experimental perturbations or conditions that affect replication timing (RT), arranged according to the percentage of genome affected, from least affected (top) to most affected (bottom)

\begin{tabular}{ll}
\hline Conditions & \multicolumn{1}{c}{ Reference } \\
\hline $\begin{array}{l}\text { Conditions with no to few localized } \\
\text { effects on RT }\end{array}$ & \\
Mother-daughter pairs & Ryba et al. 2012 \\
Individual variation & Pope et al. 2011, Ryba \\
& et al. 2012 \\
FSHD versus normal myoblasts & Pope et al. 2011 \\
Oncogene-induced presenescence & Unpublished \\
Suz12 null & Pope et al. 2014 \\
MeCP2 null & Unpublished \\
G9a null & Yokochi et al. 2009 \\
H1c, H1d, H1e triple null & Unpublished \\
c-Myc, n-Myc double null & Unpublished \\
BAF53a null & Takebayashi et al. 2013 \\
CAPD3 knockdown & Unpublished \\
LaminB knockdown & Unpublished \\
Rb knockdown & Unpublished \\
HMGA1 knockdown & Unpublished \\
MyoD overexpress & Unpublished \\
Pax5 overexpress & Unpublished \\
CTCF null & Unpublished \\
Replicative presenescence/ & Unpublished \\
Hayflick limit & \\
Pluripotent cell growth conditions & Unpublished \\
Age & Unpublished \\
Progeria & Unpublished \\
BAF250a or Brg1 null & Takebayashi et al. 2013 \\
Conditions with widespread & \\
effects on RT & \\
Leukemia & Ryba et al. 2012 \\
Pol $\theta$ knockdown & Fernandez-Vidal et al. \\
Differentiation & 2014 \\
Rif1 null & Hiratani et al. 2008 \\
\hline & Cornacchia et al. 2012 \\
\hline FSH, & \\
\hline
\end{tabular}

FSHD, facioscapulohumeral dystrophy; CTCF, CCCTC-binding factor.

replication within 45-60 $\mathrm{min}$ and are stable structural units of $0.5-1 \mathrm{Mb}$ (Nakamura et al. 1986; Nakayasu and Berezney 1989; O'Keefe et al. 1992; Jackson and Pombo 1998; Ma et al. 1998; Dimitrova and Gilbert 1999; Sadoni et al. 2004; Maya-Mendoza et al. 2010). Because DNA fiber studies show coordinate firing of multiple origins ("replicon clusters") across hundreds of kilobases (Berezney et al. 2000), replication foci likely correspond to replicon clusters. Further, differentially labeling early and late replicating DNA showed that early and late foci reside in distinct spatially separated compartments of the nucleus (Sparvoli et al. 1994; Ferreira and Carmo-Fonseca 1997; Jackson and Pombo 1998). More recently, RT comparison of distinct cell types showed that developmentally regulated RDs were uniform in size, on the order of 400-800 kb, defining a minimal unit of RT control (Hiratani et al. 2008, 2010; Rivera-Mulia et al. 2015), consistent with the size of replication foci. The much larger CTRs seen in RT profiles are also consistent with the finding that groups of adjacent replication foci replicate sequentially within 1$2 \mathrm{~h}$ of each other (Sporbert et al. 2002; Sadoni et al. 2004), which could explain many of the submegabase peaks and valleys (ripples) observed within CTRs. 
The discovery of genomic units of RT regulation lead us to propose a large-scale "beads on a string" model for the spatiotemporal regulation of DNA replication, which we refer to as the "RD model" (Hiratani et al. 2008). It is now important to test the equivalence of these units to those measured by different methods. First, a proper computational analysis of ripples is needed to decipher their reproducibility and to distinguish regions of high initiation potential within RDs. Second, advances in DNA fiber analyses could elucidate the distribution of origins and forks across the genome to reveal whether domains with definable boundaries indeed exist. Finally, combined replication labeling with fluorescence in situ hybridization (FISH) could link replication foci to chromosome map units directly.

\section{TADs EQUAL RDs: LINKING STRUCTURAL UNITS TO FUNCTIONAL UNITS}

A major breakthrough came with the development of methods to map chromatin 3D interactions genome-wide (Hi-C). The first Hi-C study (Lieberman-Aiden et al. 2009) reported that chromatin is organized into two spatially distinct, mutually exclusive compartments with boundaries separating interactions between alternate compartments. Surprisingly, we found a strong correlation between early and late RT to the A/B compartments, better than any other chromosomal property analyzed to date (Fig. 1B; Ryba et al. 2010). In fact, even the subtle variations in RT (ripples) match subtle variations in contact frequencies. Higher resolution Hi-C produced even higher correlations to RT and identified the existence of substructures in the interaction maps that were termed topologically associating domains (TADs) (Dixon et al. 2012; Nora et al. 2012; Rao et al. 2014). This raised the hypothesis that TADs might be RDs. By mapping $\mathrm{RD}$ boundaries in several different cell types, we found that indeed there is a "near one to one" correspondence of TAD boundaries and the early border of the TTR. Further analysis demarcated RD boundaries at the early borders of TTRs as a major point of chromatin state bifurcation (Pope et al. 2014).

Thus RT is regulated at the level of TADs; multiple TADs replicate at the same time to form CTRs and chromatin folds in such a way that CTRs that reside in the same interaction compartment replicate at similar times. Consistently, changes in subnuclear position correlate with changes in RT during development (Williams et al. 2006; Hiratani et al. 2008, 2010). Further, developmental changes in the RT of a domain are accompanied by the reestablishment of chromatin contacts between the domain and other regions of similar RT (Takebayashi et al. 2012; Denholtz et al. 2013). Consistently, the changes observed by artificial perturbations of chromatin structure-for example, RT alterations in Rif1 or BAF250a mutants and in leukemia (Table 1) -align with TAD/RD boundaries (Ryba et al. 2012; V Dileep, unpubl.). These observations suggest that cis-acting elements at the early replicating border of TTRs may act as boundaries to confine units of RT regulation. More direct evidence for the insulating effect of TTRs comes from the analysis of RT on a rearranged human chromosome in mouse cells, which found that when two regions that replicate at different times were juxtaposed, early replication spread into the late domains, but the spread was limited to the closest TTR (Pope et al. 2012).

\section{FORMATION OF TADS AND NUCLEAR COMPARTMENTS COINCIDE WITH ESTABLISHMENT OF RT}

Another compelling link between RT and the spatial compartmentalization of chromatin was that RT is established coincident with the global repositioning and anchorage of chromatin as the nucleus is reassembled during early $\mathrm{G}_{1}$ phase (Dimitrova and Gilbert 1999), at a point we termed the TDP (timing decision point). The observation that the interphase organization of the genome is disrupted during mitosis and reestablished in $G_{1}$ phase (Naumova et al. 2013) suggested that reestablishment of TADs and inter-TAD contacts might coincide with the TDP. To test this hypothesis, we used multiplexed 4C-seq to study dynamic changes in chromatin organization during early $G_{1}$. Both the establishment of TADs and their compartmentalization occurred within the same time frame as the TDP (Fig. 2; Dileep et al. 2015).

The concurrent reestablishment of both RT and chromatin organization at TDP suggests a model in which RT could be the functional consequence of interphase chromatin organization during early $\mathrm{G}_{1}$. In contrast, $\mathrm{G}_{2}$ phase is a period where RT determinants are lost but the interphase spatial organization of chromatin remains unchanged ( $\mathrm{Lu}$ et al. 2010). In fact, $4 \mathrm{C}$-seq in $\mathrm{G}_{2}$ phase revealed that the TAD structure and the inter-TAD contacts that establish the nuclear compartments are still preserved in $\mathrm{G}_{2}$ (Dileep et al. 2015). Hence, although chromatin contacts may be necessary to establish RT, those chromatin contacts are not sufficient to dictate the RT program in the $\mathrm{G}_{2}$ nuclei. Together, these results support a model where the formation of TADs and their segregation into distinct nuclear compartments serves as a scaffold that seeds the assembly of RDs that are enriched or depleted for factors that modulate the efficiency of origin firing such as Rifl (Gilbert 2001; Dileep et al. 2015). The loss of timing program in $\mathrm{G}_{2}$ may be due to the dilution or relocation of these chromatin components during replication.

\section{RDS THAT SWITCH RT ARE DIFFERENT FROM CONSTITUTIVE RDS}

The genome consists of domains that replicate either early or late in all cell types (constitutive domains) or domains that can switch RT from early to late or late to early during the course of differentiation (developmental domains). Generally, more open and transcriptionally active early replicating chromatin is in the nuclear interior and closed transcriptionally silent late replicating chromatin is located closer to the nuclear periphery (Rhind 

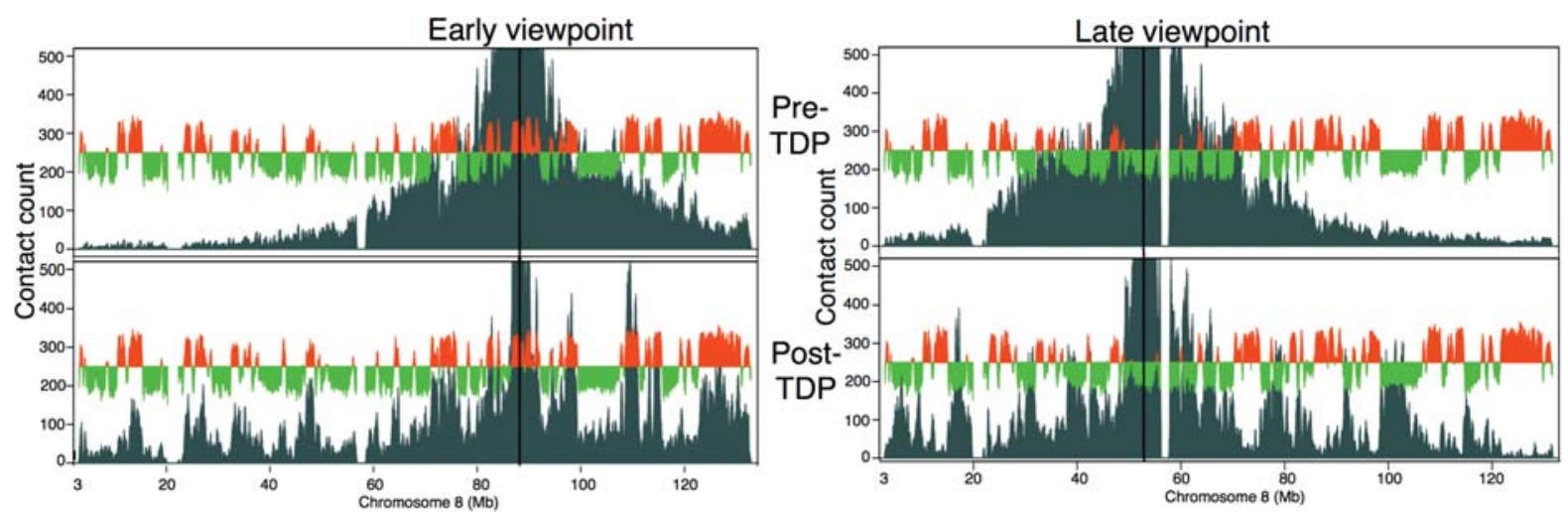

Figure 2. Reestablishment of chromatin structure during the timing decision point. Smoothed 4C data (dark gray) overlaid with the RT profile (red/green is early/late replicating) for a late replicating viewpoint and an early replicating viewpoint. Vertical black lines indicate position of the $4 \mathrm{C}$ viewpoint. $4 \mathrm{C}$ viewpoints before TDP interacted preferentially with the chromatin that is close along the liner distance, regardless of their RT. But after the TDP, the interactions showed a strong preference to regions of similar RT and interactions dropped off precipitously at RD boundaries.

and Gilbert 2013). A surprise, however, was that many of these correlations that have dominated the literature for decades are applicable to constitutive but not developmental domains. Although constitutive domains are either strongly compartmentalized to the nuclear interior (constitutive early domains) or to the nuclear periphery (constitutive late domains), developmental regions are more plastic in their compartmentalization, regardless of early or late RT. A systematic analysis of several histone modifications and transcription factors showed that enrichment of these features was correlated to RT for constitutive domains, whereas developmental domains showed moderate enrichment that was less correlated to RT (Dileep et al. 2015). This finding is consistent with several other studies showing that developmental domains are distinct as measured by several global features of the chromatin as summarized in Table 2 (Besnard et al. 2012; Takebayashi et al. 2012; Lubelsky et al. 2014; Rivera-Mulia et al. 2015).

\section{RT AND GENE EXPRESSION: A COMPLEX RELATIONSHIP}

Despite the strong correlation between RT program and gene expression observed for decades (Goldman et al. 1984; Hatton et al. 1988; Gilbert 2002), mechanistic and causal relationships remain elusive. Early observations found that regions of the genome that are heterochromatic (Lima-de-Faria 1959; Taylor 1960; Baer 1965; Himes 1967) and/or less transcriptionally active (Hsu et al. 1964; Berlowitz 1965) replicate late during S phase. In contrast, DNA replicated early during $\mathrm{S}$ phase contains most active genes (Klevecz and Stubblefield 1967; Pfeiffer and Tolmach 1968). Studies of individual gene RT showed that constitutively active genes replicate early, whereas tissue-specific genes replicate early only in cell types where they were active (Goldman et al. 1984; Gilbert 1986; Holmquist 1987; Selig et al. 1992; Ermakova et al. 1999; Simon et al. 2001). Further characterization identified developmentally regulated RT switches that encompass hundreds of kilobases that were coincident with transcriptional activation of genes within the affected domain (Hiratani et al. 2004, 2008; Perry et al. 2004).

With the advent of genome-wide studies, the global correlation between early replication and active gene expression has been confirmed in all multicellular organisms studied (Schübeler et al. 2002; MacAlpine et al. 2004; Woodfine et al. 2004; Huvet et al. 2007; Hiratani et al. 2008; Desprat et al. 2009; Hiratani and Gilbert 2009; Schwaiger et al. 2009; Maric and Prioleau 2010; Lubelsky et al. 2014). Moreover, development changes in the RT program are closely coordinated with transcriptional competence (Zhou et al. 2002; Hiratani et al. 2008, 2010; Desprat et al. 2009; Schultz et al. 2010; Yue et al. 2014). However, the dynamic changes in RT and gene expression were so coincident that the order of events was not determined and causal relationships remained unsolved. In addition, closer inspection of the genome-wide studies showed that the relationship between transcription and RT is clearly indirect, because changes in gene expression can occur without alterations in RT and $\sim 20 \%$ of

Table 2. Comparison of chromatin features between constitutive early and late (CE, CL) and developmental replication domains that are either early (DE) or late (DL) in the particular cell type analyzed for each respective chromatin feature

\begin{tabular}{llllc}
\hline Property & CE & CL & DE & DL \\
\hline Degree of compartmentalization & High & High & Low & Low \\
MNase sensitivity, origin density & High & Low & Low & Low \\
LaminB association & Low & High & Moderately low & Moderately high \\
42 trans-acting factors (e.g., CTCF, EZH2), chromatin marks:H3K27ac, & Enriched & Depleted Moderately & Moderately \\
H3K4me1, H3K4me2, H3K9ac, H4K20me1, H2az & & & enriched & depleted \\
\hline
\end{tabular}


late replicating genes are expressed (Schübeler et al. 2002, 2004; Hiratani et al. 2008, 2010).

To investigate the intriguing liaisons between RT and gene expression, we recently analyzed their coordinated changes during cell fate commitment (Rivera-Mulia et al. 2015). By taking advantage of optimized methods for human embryonic stem cell differentiation (Schulz et al. 2012; Menendez et al. 2013; Rivera-Mulia et al. 2015) and analyzing multiple cell types and differentiation intermediates, we characterized the establishment of cell typespecific RT programs and differential gene expression. We observed highly coordinated kinetics of RT and tran- scriptional changes; however, our study also revealed that the strong correlation between early replication and active transcription is restricted to RT constitutive genes (i.e., genes that do not change their RT program), whereas the RT switching genes have a weaker correlation that is lost during differentiation. Deeper analysis showed distinct classes of genes, among those, some are expressed only when they replicate early (E-class), whereas others can be expressed when they replicate late (C-class) (Fig. 3A,B). Surprisingly, the majority of RT switching genes belong to the C-class category and are strongly expressed in one or more cell types while late replicating, demonstrating
A

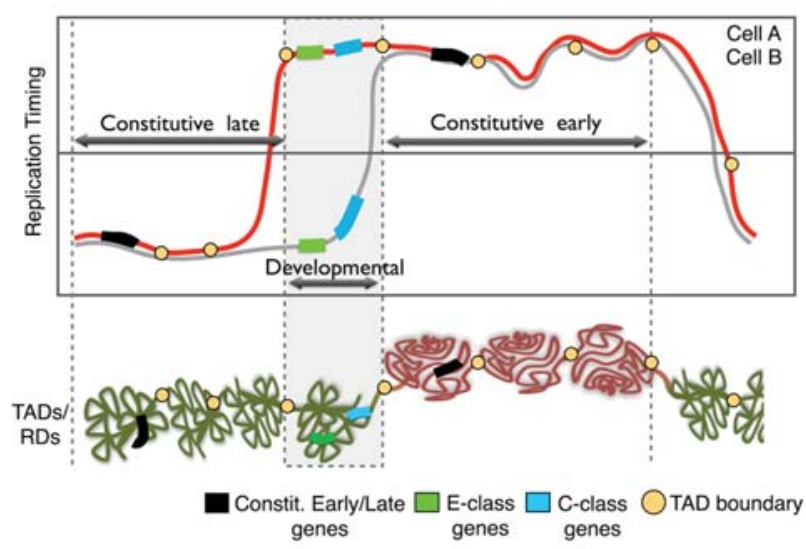

B

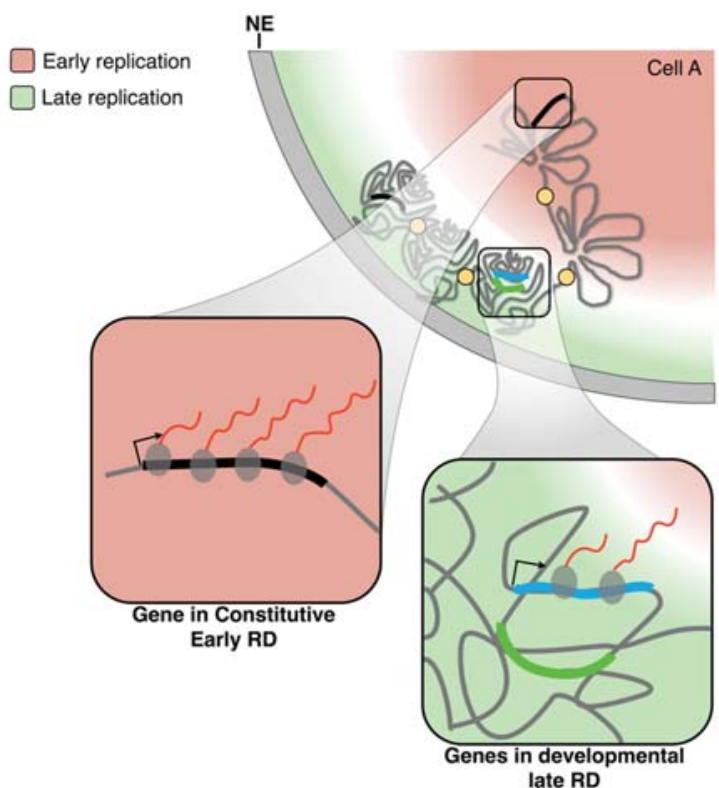

C
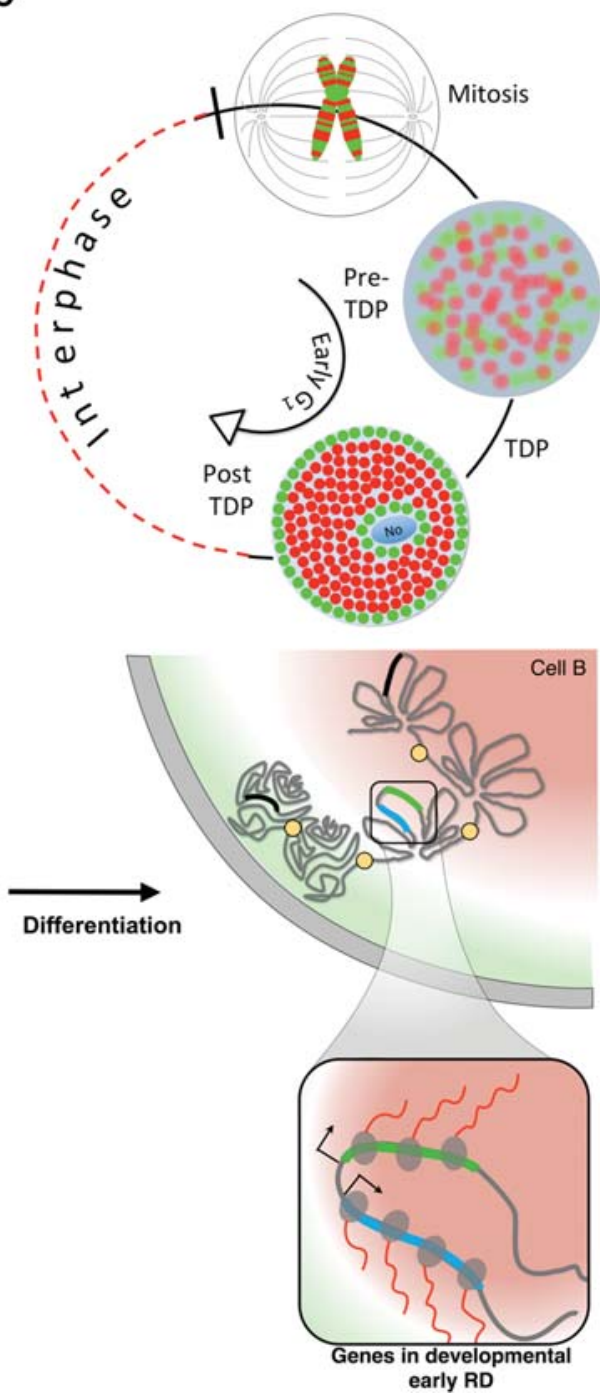

Figure 3. Cell cycle and developmental regulation of replication domains (RDs): The RD model. ( $A$ ) RDs correspond to topologically associating domains (TADs). Replication timing (RT) profiles of two hypothetical cell types illustrate an RD that changes RT (developmental RD) and RDs that replicate either early or late in all cell types (constitutive RD). Genes in constitutive early/late RDs are colored black. E-class and C-class genes are shown in green and blue, respectively. $(B)$ Early replicating RDs are more open and positioned toward the interior and late replicating RDs are closed and positioned near nuclear periphery. Late RDs and their adjacent timing transition regions (TTRs) associate with the nuclear lamina to form lamina-associated domains (LADs). During differentiation, developmental RDs move toward or away from nuclear lamina depending on the direction of the RT switch. Expression of E-class genes is closely linked to RT and is expressed coordinately with their switch toward early replication, whereas C-class genes are less correlated to RT and are generally turned on before their switch to early replication. $(C)$ Formation of TADs and their segregation into early/late compartments both coincide with establishment of RT during TDP. 
that transcription is not sufficient for early replication. Additionally, a rare category of genes (L-class) contains RT switching genes that were expressed exclusively when replicated late. Interestingly, transcriptional activity of $\mathrm{C}$-class genes is still coordinated with RT, despite their ability to be transcribed when replicated late. However, an increase in expression levels is commonly observed before changes to early replication, whereas changes to late RT are followed by down-regulation (Rivera-Mulia et al. 2015). These results suggest either that aspects of transcriptional control can indirectly influence RT or that different RDs are regulated by different mechanisms. Manipulative experiments are now imperative to dissect the mechanisms linking transcription and RT.

\section{CONCLUSION: THE RD MODEL}

Here, we finish with a unifying large-scale structurefunction model that incorporates recent findings linking RT to chromatin 3D structure (Fig. 3). Our model has two main tenets. First, RT is regulated at the level of TADs that are stable across cell types (Pope et al. 2014; Dixon et al. 2015). Second, TADs that replicate at similar times frequently interact with each other, dividing the genome into two distinct spatially separated nuclear compartments. Consistently, early replication is associated with the nuclear interior, whereas late replication is observed near the nuclear periphery (Rhind and Gilbert 2013). Late replicating RDs together with TTRs associate with the nuclear lamina to form lamina-associated domains (Fig. 3B; Peric-Hupkes et al. 2010; Pope et al. 2014). Thus, the segregation of RDs/TADs into these early or late replicating compartments reflects each cell type's unique RT program. This organization persists throughout interphase but is dismantled during mitosis (Naumova et al. 2013) and reestablished coincident with the establishment of RT early in $\mathrm{G}_{1}$ (Fig. 3C; Dileep et al. 2015). This emerging view of the genome recognizes RDs/TADs as epigenetic modules whose chromatin features are regulated during cell fate transitions. These features include RT, chromatin marks, chromatin accessibility, and 3D organization (Rhind and Gilbert 2013), which all affect gene regulation. Because disruption of TADs and misregulation of its properties could result in disease states (Ryba et al. 2012; Lupiáñez et al.2015), a critical issue to be resolved now is the extent to which TAD structure is a cause or consequence of genome function. We predict that studies of RT using modern "domain engineering" methods will provide important insight into this question.

\section{ACKNOWLEDGMENTS}

Research in the Gilbert laboratory is supported by National Institutes of Health (NIH) grants GM083337 and GM085354.

\section{REFERENCES}

Aladjem MI, Rodewald LW, Lin CM, Bowman S, Cimbora DM, Brody LL, Epner EM, Groudine M, Wahl GM. 2002. Repli- cation initiation patterns in the $\beta$-globin loci of totipotent and differentiated murine cells: Evidence for multiple initiation regions. Mol Cell Biol 22: 442-452.

Baer D. 1965. Asynchronous replication of DNA in a heterochromatic set of chromosomes in Pseudococcus obscurus. Genetics 52: 275-285.

Bartholdy B, Mukhopadhyay R, Lajugie J, Aladjem MI, Bouhassira EE. 2015. Allele-specific analysis of DNA replication origins in mammalian cells. Nat Commun 6: 7051.

Bechhoefer J, Rhind N. 2012. Replication timing and its emergence from stochastic processes. Trends Genet 28: 374-381.

Berezney R, Dubey DD, Huberman JA. 2000. Heterogeneity of eukaryotic replicons, replicon clusters, and replication foci. Chromosoma 108: 471-484.

Berlowitz L. 1965. Correlation of genetic activity, heterochromatization, and RNA metabolism. Proc Natl Acad Sci 53: $68-73$.

Besnard E, Babled A, Lapasset L, Milhavet O, Parrinello H, Dantec C, Marin JM, Lemaitre JM. 2012. Unraveling cell type-specific and reprogrammable human replication origin signatures associated with G-quadruplex consensus motifs. Nat Struct Mol Biol 19: 837-844.

Blow JJ, Ge XQ. 2009. A model for DNA replication showing how dormant origins safeguard against replication fork failure. EMBO Rep 10: 406-412.

Cayrou C, Coulombe P, Vigneron A, Stanojcic S, Ganier O, Peiffer I, Rivals E, Puy A, Laurent-Chabalier S, Desprat R, et al. 2011. Genome-scale analysis of metazoan replication origins reveals their organization in specific but flexible sites defined by conserved features. Genome Res 21: 14381449.

Cornacchia D, Dileep V, Quivy JP, Foti R, Tili F, SantarellaMellwig R, Antony C, Almouzni G, Gilbert DM, Buonomo SB. 2012. Mouse Rif1 is a key regulator of the replicationtiming programme in mammalian cells. EMBO J 31: $3678-$ 3690 .

Craig JM, Bickmore WA. 1993. Chromosome bands-Flavours to savour. Bioessays 15: 349-354.

Denholtz M, Bonora G, Chronis C, Splinter E, de Laat W, Ernst J, Pellegrini M, Plath K. 2013. Long-range chromatin contacts in embryonic stem cells reveal a role for pluripotency factors and polycomb proteins in genome organization. Cell Stem Cell 13: 602-616.

Desprat R, Thierry-Mieg D, Lailler N, Lajugie J, Schildkraut C, Thierry-Mieg J, Bouhassira EE. 2009. Predictable dynamic program of timing of DNA replication in human cells. Genome Res 19: 2288-2299.

Dileep V, Didier R, Gilbert DM. 2012. Genome-wide analysis of replication timing in mammalian cells: Troubleshooting problems encountered when comparing different cell types. Methods 57: 165-169.

Dileep V, Ay F, Sima J, Vera DL, Noble WS, Gilbert DM. 2015. Topologically associating domains and their long-range contacts are established during early $\mathrm{G}_{1}$ coincident with the establishment of the replication-timing program. Genome Res 25: $1104-1113$.

Dimitriadou E, Van der Aa N, Cheng J, Voet T, Vermeesch JR. 2014. Single cell segmental aneuploidy detection is compromised by S phase. Mol Cytogenet 7: 46.

Dimitrova DS, Gilbert DM. 1999. The spatial position and replication timing of chromosomal domains are both established in early G1 phase. Mol Cell 4: 983-993.

Di Rienzi SC, Lindstrom KC, Mann T, Noble WS, Raghuraman MK, Brewer BJ. 2012. Maintaining replication origins in the face of genomic change. Genome Res 22: 1940-1952.

Dixon JR, Selvaraj S, Yue F, Kim A, Li Y, Shen Y, Hu M, Liu JS, Ren B. 2012. Topological domains in mammalian genomes identified by analysis of chromatin interactions. Nature 485 : $376-380$.

Dixon JR, Jung I, Selvaraj S, Shen Y, Antosiewicz-Bourget JE, Lee AY, Ye Z, Kim A, Rajagopal N, Xie W, et al. 2015. Chromatin architecture reorganization during stem cell differentiation. Nature 518: 331-336. 
Ermakova GV, Alexandrova EM, Kazanskaya OV, Vasiliev OL, Smith MW, Zaraisky AG. 1999. The homeobox gene, Xanf-1, can control both neural differentiation and patterning in the presumptive anterior neurectoderm of the Xenopus laevis embryo. Development 126: 4513-4523.

Farkash-Amar S, Lipson D, Polten A, Goren A, Helmstetter C, Yakhini Z, Simon I. 2008. Global organization of replication time zones of the mouse genome. Genome Res 18: 1562 1570.

Fernandez-Vidal A, Guitton-Sert L, Cadoret JC, Drac M, Schwob E, Baldacci G, Cazaux C, Hoffmann JS. 2014. A role for DNA polymerase $\theta$ in the timing of DNA replication. Nat Commun 5: 4285.

Ferreira J, Carmo-Fonseca M. 1997. Genome replication in early mouse embryos follows a defined temporal and spatial order. J Cell Sci 110: 889-897.

Gilbert DM. 1986. Temporal order of replication of Xenopus laevis 5S ribosomal RNA genes in somatic cells. Proc Natl Acad Sci 83: 2924-2928.

Gilbert DM. 2001. Nuclear position leaves its mark on replication timing. J Cell Biol 152: F11-F15.

Gilbert DM. 2002. Replication timing and transcriptional control: Beyond cause and effect. Curr Opin Cell Biol 14: $377-$ 383.

Gilbert DM. 2010. Evaluating genome-scale approaches to eukaryotic DNA replication. Nat Rev Genet 11: 673-684.

Goldman MA, Holmquist GP, Gray MC, Caston LA, Nag A. 1984. Replication timing of genes and middle repetitive sequences. Science 224: 686-692.

Guan Z, Hughes CM, Kosiyatrakul S, Norio P, Sen R, Fiering S, Allis CD, Bouhassira EE, Schildkraut CL. 2009. Decreased replication origin activity in temporal transition regions. $J$ Cell Biol 187: 623-635.

Guilbaud G, Rappailles A, Baker A, Chen CL, Arneodo A, Goldar A, d'Aubenton-Carafa Y, Thermes C, Audit B, Hyrien O. 2011. Evidence for sequential and increasing activation of replication origins along replication timing gradients in the human genome. PLoS Comput Biol 7: e1002322.

Hamlin JL, Mesner LD, Lar O, Torres R, Chodaparambil SV, Wang L. 2008. A revisionist replicon model for higher eukaryotic genomes. J Cell Biochem 105: 321-329.

Hansen RS, Thomas S, Sandstrom R, Canfield TK, Thurman RE, Weaver M, Dorschner MO, Gartler SM, Stamatoyannopoulos JA. 2010. Sequencing newly replicated DNA reveals widespread plasticity in human replication timing. Proc Nat Acad Sci 107: 139-144.

Hatton KS, Dhar V, Brown EH, Iqbal MA, Stuart S, Didamo VT, Schildkraut CL. 1988. Replication program of active and inactive multigene families in mammalian cells. Mol Cell Biol 8: $2149-2158$.

Hause RJ, Shendure J. 2014. Genetic variation meets replication origins. Cell 159: 973-974.

Hayano M, Kanoh Y, Matsumoto S, Renard-Guillet C, Shirahige $\mathrm{K}$, Masai H. 2012. Rif1 is a global regulator of timing of replication origin firing in fission yeast. Genes Dev 26: 137 150

Himes M. 1967. An analysis of heterochromatin in maize root tips. J Cell Biol 35: 175-181.

Hiratani I, Gilbert DM. 2009. Replication timing as an epigenetic mark. Epigenetics 4: 93-97.

Hiratani I, Leskovar A, Gilbert DM. 2004. Differentiation-induced replication-timing changes are restricted to AT-rich/ long interspersed nuclear element (LINE)-rich isochores. Proc Natl Acad Sci 101: 16861-16866.

Hiratani I, Ryba T, Itoh M, Yokochi T, Schwaiger M, Chang CW, Lyou Y, Townes TM, Schübeler D, Gilbert DM. 2008. Global reorganization of replication domains during embryonic stem cell differentiation. PLoS Biol 6: e245.

Hiratani I, Ryba T, Itoh M, Rathjen J, Kulik M, Papp B, Fussner E, Bazett-Jones DP, Plath K, Dalton S, et al. 2010. Genomewide dynamics of replication timing revealed by in vitro models of mouse embryogenesis. Genome Res 20: 155-169.
Holmquist GP. 1987. Role of replication time in the control of tissue-specific gene expression. Am J Hum Genet 40: $151-173$

Holmquist G, Gray M, Porter T, Jordan J. 1982. Characterization of Giemsa dark- and light-band DNA. Cell 31: 121-129.

Hoshi O, Ushiki T. 2011. Replication banding patterns in human chromosomes detected using 5-ethynyl- $2^{\prime}$-deoxyuridine incorporation. Acta Histochem Cytochem 44: 233-237.

Hsu TC, Schmid W, Stubblefield E. 1964. DNA replication sequences in higher mammals. In The role of chromosomes in development (ed. Locke M), pp. 83-112. Academic Press, New York.

Huvet M, Nicolay S, Touchon M, Audit B, d'Aubenton-Carafa Y, Arneodo A, Thermes C. 2007. Human gene organization driven by the coordination of replication and transcription. Genome Res 17: 1278-1285.

Jackson DA, Pombo A. 1998. Replicon clusters are stable units of chromosome structure: Evidence that nuclear organization contributes to the efficient activation and propagation of $S$ phase in human cells. J Cell Biol 140: 1285-1295.

Klevecz RR, Stubblefield E. 1967. RNA synthesis in relation to DNA replication in synchronized Chinese hamster cell cultures. J Exp Zool 165: 259-268.

Koren A, Handsaker RE, Kamitaki N, Karlić R, Ghosh S, Polak P, Eggan K, McCarroll SA. 2014. Genetic variation in human DNA replication timing. Cell 159: 1015-1026.

Latt SA. 1977. Fluorescent probes of chromosome structure and replication. Can J Genet Cytol 19: 603-623.

Lebofsky R, Heilig R, Sonnleitner M, Weissenbach J, Bensimon A. 2006. DNA replication origin interference increases the spacing between initiation events in human cells. Mol Biol Cell 17: 5337-5345.

Letessier A, Millot GA, Koundrioukoff S, Lachagès AM, Vogt N, Hansen RS, Malfoy B, Brison O, Debatisse M. 2011. Celltype-specific replication initiation programs set fragility of the FRA3B fragile site. Nature 470: 120-123.

Liachko I, Bhaskar A, Lee C, Chung SC, Tye BK, Keich U. 2010. A comprehensive genome-wide map of autonomously replicating sequences in a naive genome. PLoS Genet 6: e1000946.

Lieberman-Aiden E, van Berkum NL, Williams L, Imakaev M, Ragoczy T, Telling A, Amit I, Lajoie BR, Sabo PJ, Dorschner MO, et al. 2009. Comprehensive mapping of long range interactions reveals folding principles of the human genome. Science 326: 289-293.

Lima-de-Faria A. 1959. Differential uptake of tritiated thymidine into hetero- and euchromatin in Melanoplus and Secale. J Biophys Biochem Cytol 6: 457-466.

Lu J, Li F, Murphy CS, Davidson MW, Gilbert DM. 2010. G2 phase chromatin lacks determinants of replication timing. $J$ Cell Biol 189: 967-980.

Lubelsky Y, Prinz JA, DeNapoli L, Li Y, Belsky JA, MacAlpine DM. 2014. DNA replication and transcription programs respond to the same chromatin cues. Genome Res 24: 1102 1114.

Lupiáñez DG, Kraft K, Heinrich V, Krawitz P, Brancati F, Klopocki E, Horn D, Kayserili H, Opitz JM, Laxova R, et al. 2015. Disruptions of topological chromatin domains cause pathogenic rewiring of gene-enhancer interactions. Cell 161: $1012-1025$.

Ma H, Samarabandu J, Devdhar RS, Acharya R, Cheng PC, Meng C, Berezney R. 1998. Spatial and temporal dynamics of DNA replication sites in mammalian cells. J Cell Biol 143: 1415-1425.

MacAlpine DM, Rodríguez HK, Bell SP. 2004. Coordination of replication and transcription along a Drosophila chromosome. Genes Dev 18: 3094-3105.

Manukjan G, Tauscher M, Steinemann D. 2013. Replication timing influences DNA copy number determination by array-CGH. Biotechniques 55: 231-232.

Maric C, Prioleau MN. 2010. Interplay between DNA replication and gene expression: A harmonious coexistence. Curr Opin Cell Biol 22: 277-283. 
Maya-Mendoza A, Olivares-Chauvet P, Shaw A, Jackson DA. 2010. S phase progression in human cells is dictated by the genetic continuity of DNA foci. PLoS Genet 6: e1000900.

Menendez L, Kulik MJ, Page AT, Park SS, Lauderdale JD, Cunningham ML, Dalton S. 2013. Directed differentiation of human pluripotent cells to neural crest stem cells. Nat Protoc 8: 203-212.

Meselson M, Stahl FW. 1958. The replication of DNA in Escherichia coli. Proc Natl Acad Sci 44: 671-682.

Moindrot B, Audit B, Klous P, Baker A, Thermes C, de Laat W, Bouvet P, Mongelard F, Arneodo A. 2012. 3D chromatin conformation correlates with replication timing and is conserved in resting cells. Nucleic Acids Res 40: 94709481.

Mukhopadhyay R, Lajugie J, Fourel N, Selzer A, Schizas M, Bartholdy B, Mar J, Lin CM, Martin MM, Ryan M, et al. 2014. Allele-specific genome-wide profiling in human primary erythroblasts reveal replication program organization. PLoS Genet 10: e1004319.

Müller CA, Nieduszynski CA. 2012. Conservation of replication timing reveals global and local regulation of replication origin activity. Genome Res 22: 1953-1962.

Nakamura H, Morita T, Sato C. 1986. Structural organizations of replicon domains during DNA synthetic phase in the mammalian nucleus. Exp Cell Res 165: 291-297.

Nakayasu H, Berezney R. 1989. Mapping replicational sites in the eucaryotic cell nucleus. J Cell Biol 108: $1-11$.

Naumova N, Imakaev M, Fudenberg G, Zhan Y, Lajoie BR, Mirny LA, Dekker J. 2013. Organization of the mitotic chromosome. Science 342: 948-953.

Nora EP, Lajoie BR, Schulz EG, Giorgetti L, Okamoto I, Servant N, Piolot T, van Berkum NL, Meisig J, Sedat J, et al. 2012. Spatial partitioning of the regulatory landscape of the Xinactivation centre. Nature 485: 381-385.

Norio P, Schildkraut CL. 2001. Visualization of DNA replication on individual Epstein-Barr virus episomes. Science 294: $2361-2364$.

Norio P, Kosiyatrakul S, Yang Q, Guan Z, Brown NM, Thomas S, Riblet R, Schildkraut CL. 2005. Progressive activation of DNA replication initiation in large domains of the immunoglobulin heavy chain locus during B cell development. Mol Cell 20: $575-587$.

O'Keefe RT, Henderson SC, Spector DL. 1992. Dynamic organization of DNA replication in mammalian cell nuclei: Spatially and temporally defined replication of chromosomespecific $\alpha$-satellite DNA sequences. J Cell Biol 116: $1095-$ 1110.

Peric-Hupkes D, Meuleman W, Pagie L, Bruggeman SW, Solovei I, Brugman W, Gräf S, Flicek P, Kerkhoven RM, van Lohuizen M, et al. 2010. Molecular maps of the reorganization of genome-nuclear lamina interactions during differentiation. Mol Cell 38: 603-613.

Perry P, Sauer S, Billon N, Richardson WD, Spivakov M, Warnes G, Livesey FJ, Merkenschlager M, Fisher AG, Azuara V. 2004. A dynamic switch in the replication timing of key regulator genes in embryonic stem cells upon neural induction. Cell Cycle 3: 1645-1650.

Pfeiffer SE, Tolmach LJ. 1968. RNA synthesis in synchronously growing populations of HeLa S3 cells. I. Rate of total RNA synthesis and its relationship to DNA synthesis. J Cell Physiol 71: 77-93.

Pope BD, Tsumagari K, Battaglia D, Ryba T, Hiratani I, Ehrlich M, Gilbert DM. 2011. DNA replication timing is maintained genome-wide in primary human myoblasts independent of D4Z4 contraction in FSH muscular dystrophy. PLoS One 6: e27413.

Pope BD, Chandra T, Buckley Q, Hoare M, Ryba T, Wiseman FK, Kuta A, Wilson MD, Odom DT, Gilbert DM. 2012. Replication-timing boundaries facilitate cell-type and speciesspecific regulation of a rearranged human chromosome in mouse. Hum Mol Genet 21: 4162-4170.

Pope BD, Ryba T, Dileep V, Yue F, Wu W, Denas O, Vera DL, Wang Y, Hansen RS, Canfield TK, et al. 2014. Topologically associating domains are stable units of replication-timing regulation. Nature 515: 402-405.

Rao SS, Huntley MH, Durand NC, Stamenova EK, Bochkov ID, Robinson JT, Sanborn AL, Machol I, Omer AD, Lander ES, et al. 2014. A 3D map of the human genome at kilobase resolution reveals principles of chromatin looping. Cell 159: $1665-1680$.

Rhind N, Gilbert DM. 2013. DNA replication timing. Cold Spring Harb Perspect Med 3: 1-26.

Rivera-Mulia JC, Buckley Q, Sasaki T, Zimmerman J, Didier RA, Nazor K, Loring JF, Lian Z, Weissman S, Robins AJ, et al. 2015. Dynamic changes in replication timing and gene expression during lineage specification of human pluripotent stem cells. Genome Res 25: 1091-1103.

Ryba T, Hiratani I, Lu J, Itoh M, Kulik M, Zhang J, Dalton S, Gilbert DM, Schulz TC, Robins AJ, et al. 2010. Evolutionarily conserved replication timing profiles predict long-range chromatin interactions and distinguish closely related cell types. Genome Res 20: 761-770.

Ryba T, Battaglia D, Pope BD, Hiratani I, Gilbert DM. 2011a. Genome-scale analysis of replication timing: From bench to bioinformatics. Nat Protoc 6: 870-895.

Ryba T, Hiratani I, Sasaki T, Battaglia D, Kulik M, Zhang J, Dalton S, Gilbert DM. 2011b. Replication timing: A fingerprint for cell identity and pluripotency. PLoS Comput Biol 7: e1002225.

Ryba T, Battaglia D, Chang BH, Shirley JW, Buckley Q, Pope BD, Devidas M, Druker BJ, Gilbert DM. 2012. Abnormal developmental control of replication-timing domains in pediatric acute lymphoblastic leukemia. Genome Res 22: 1833-1844.

Sadoni N, Cardoso MC, Stelzer EH, Leonhardt H, Zink D. 2004. Stable chromosomal units determine the spatial and temporal organization of DNA replication. J Cell Sci 117: $5353-5365$.

Schübeler D, Scalzo D, Kooperberg C, van Steensel B, Delrow J, Groudine M. 2002. Genome-wide DNA replication profile for Drosophila melanogaster: A link between transcription and replication timing. Nat Genet 32: 438-442.

Schübeler D, MacAlpine DM, Scalzo D, Wirbelauer C, Kooperberg C, van Leeuwen F, Gottschling DE, O'Neill LP, Turner BM, Delrow J, et al. 2004. The histone modification pattern of active genes revealed through genome-wide chromatin analysis of a higher eukaryote. Genes Dev 18: 1263-1271.

Schultz SS, Desbordes SC, Du Z, Kosiyatrakul S, Lipchina I, Studer L, Schildkraut CL. 2010. Single-molecule analysis reveals changes in the DNA replication program for the POU5F1 locus upon human embryonic stem cell differentiation. Mol Cell Biol 30: 4521-4534.

Schulz TC, Young HY, Agulnick AD, Babin MJ, Baetge EE, Bang AG, Bhoumik A, Cepa I, Cesario RM, Haakmeester C, et al. 2012. A scalable system for production of functional pancreatic progenitors from human embryonic stem cells. PLoS One 7: e37004.

Schwaiger M, Stadler MB, Bell O, Kohler H, Oakeley EJ, Schübeler D. 2009. Chromatin state marks cell-type- and gender-specific replication of the Drosophila genome. Genes Dev 23: 589-601.

Selig S, Okumura K, Ward DC, Cedar H. 1992. Delineation of DNA replication time zones by fluorescence in situ hybridization. EMBO J 11: 1217-1225.

Simon I, Tenzen T, Mostoslavsky R, Fibach E, Lande L, Milot E, Gribnau J, Grosveld F, Fraser P, Cedar H. 2001. Developmental regulation of DNA replication timing at the human $\beta$ globin locus. EMBO J 20: 6150-6157.

Sparvoli E, Levi M, Rossi E. 1994. Replicon clusters may form structurally stable complexes of chromatin and chromosomes. J Cell Sci 107: 3097-3103.

Sporbert A, Gahl A, Ankerhold R, Leonhardt H, Cardoso MC. 2002. DNA polymerase clamp shows little turnover at established replication sites but sequential de novo assembly at adjacent origin clusters. Mol Cell 10: 1355-1365.

Takebayashi S, Dileep V, Ryba T, Dennis JH, Gilbert DM. 2012. Chromatin-interaction compartment switch at developmen- 
tally regulated chromosomal domains reveals an unusual principle of chromatin folding. Proc Natl Acad Sci 109: 1257412579

Takebayashi S, Lei I, Ryba T, Sasaki T, Dileep V, Battaglia D, Gao X, Fang P, Fan Y, Esteban MA, et al. 2013. Murine esBAF chromatin remodeling complex subunits BAF250a and Brg1 are necessary to maintain and reprogram pluripotency-specific replication timing of select replication domains. Epigenetics Chromatin 6: 42.

Taylor JH. 1958. The mode of chromosome duplication in Crepis capillaris. Exp Cell Res 15: 350-357.

Taylor JH. 1960. Asynchronous duplication of chromosomes in cultured cells of Chinese hamster. J Biophys Biochem Cytol 7: 455-463.

Taylor JH, Woods PS, Hughes WL. 1957. The organization and duplication of chromosomes as revealed by autoradiographic studies using tritium-labeled thymidinee. Proc Natl Acad Sci 43: $122-128$.

Van der Aa N, Cheng J, Mateiu L, Zamani Esteki M, Kumar P, Dimitriadou E, Vanneste E, Moreau Y, Vermeesch JR, Voet T. 2013. Genome-wide copy number profiling of single cells in S-phase reveals DNA-replication domains. Nucleic Acids Res 41: e66.

Williams RR, Azuara V, Perry P, Sauer S, Dvorkina M, Jørgensen H, Roix J, McQueen P, Misteli T, Merkenschlager M, et al. 2006. Neural induction promotes large-scale chro- matin reorganisation of the Mash1 locus. J Cell Sci 119: 132 140.

Woodfine K, Fiegler H, Beare DM, Collins JE, McCann OT, Young BD, Debernardi S, Mott R, Dunham I, Carter NP. 2004. Replication timing of the human genome. Hum Mol Genet 13: 191-202.

Xu J, Yanagisawa Y, Tsankov AM, Hart C, Aoki K, Kommajosyula N, Steinmann KE, Bochicchio J, Russ C, Regev A, et al. 2012. Genome-wide identification and characterization of replication origins by deep sequencing. Genome Biol 13: R27.

Yaffe E, Farkash-Amar S, Polten A, Yakhini Z, Tanay A, Simon I. 2010. Comparative analysis of DNA replication timing reveals conserved large-scale chromosomal architecture. PLoS Genet 6: e1001011.

Yokochi T, Poduch K, Ryba T, Lu J, Hiratani I, Tachibana M, Shinkai Y, Gilbert DM. 2009. G9a selectively represses a class of late-replicating genes at the nuclear periphery. Proc Natl Acad Sci 106: 19363-19368.

Yue F, Cheng Y, Breschi A, Vierstra J, Wu W, Ryba T, Sandstrom R, Ma Z, Davis C, Pope BD, et al. 2014. A comparative encyclopedia of DNA elements in the mouse genome. Nature 515: $355-364$.

Zhou J, Ermakova OV, Riblet R, Birshtein BK, Schildkraut CL. 2002. Replication and subnuclear location dynamics of the immunoglobulin heavy-chain locus in B-lineage cells. Mol Cell Biol 22: 4876-4889. 


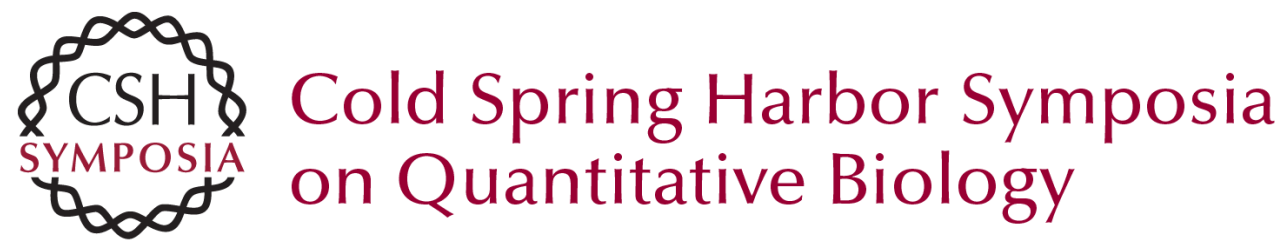

\section{Large-Scale Chromatin Structure-Function Relationships during the Cell Cycle and Development: Insights from Replication Timing}

Vishnu Dileep, Juan Carlos Rivera-Mulia, Jiao Sima, et al.

Cold Spring Harb Symp Quant Biol 2015 80: 53-63 originally published online November 20, 2015

Access the most recent version at doi:10.1101/sqb.2015.80.027284

References This article cites 110 articles, 52 of which can be accessed free at:

http://symposium.cshlp.org/content/80/53.full.html\#ref-list-1

License

Email Alerting
Service $\quad \begin{aligned} & \text { Receive free email alerts when new articles cite this article - sign up in } \\ & \text { the box at the top right corner of the article or click here. }\end{aligned}$

To subscribe to Cold Spring Harbor Symposia on Quantitative Biology go to: http://symposium.cshlp.org/subscriptions 